\title{
PENGEMBANGAN MODUL BERBASIS PENDEKATAN REALISTIC MATHEMATICS EDUCATION (RME) TERHADAP PEMAHAMAN KONSEP
}

\author{
Syafitri Wulandari ${ }^{1 *}$, Yudi Darma ${ }^{2}$, Utin Desy Susiaty ${ }^{3}$ \\ 1,2,3Pendidikan Matematika, Fakultas Pendidikan MIPA dan Teknologi IKIP PGRI Pontianak, Jalan \\ Ampera Nomor 88 Pontianak Kalimantan Barat Indonesia \\ *email: syafitriwulandari888@gmail.com
}

Received: 13 Maret 2019 Accepted: 1 Juni 2019 Published: 30 Juni 2019

\begin{abstract}
Abstrak
Penelitian ini bertujuan untuk menghasilkan modul yang berbasis pendekatan Realistic Matheatics Education (RME) terhadap pemahaman konsep dalam yang mencapai tingkat kevalidan, kepraktisan, dan keefektifan. Penelitian ini merupakan penelitian pengembangan dimana prosedur penelitian yang digunakan adalah pengembangan model 4-D yaitu define (pendefinisian), design (perancangan), development (pengembangan) dan dessiminate (penyebaran) yang dikembangkan oleh Thiagarajan pada tahun 1974. Hasil penelitian yang pertama adalah validitas modul dengan persentase sebesar 91,74\% dalam kriteria sangat valid. Yang kedua adalah nilai kepratisan dengan persentase sebesar 82,26\% dalam kriteria sangat praktis. Yang ketiga adalah nilai keefektifan diperoleh nilai sebesar 75,61\% dalam kriteria efektif. Dengan demikian dapat disimpulkan bahwa pengembangan modul berbasis pendekatan Realistic Mathematics Education (RME) terhadap pemahaman konsep tergolong valid, praktis dan efektif untuk digunakan.
\end{abstract}

Kata kunci: pemahaman konsep, Realistic Mathematics Education (RME), modul

\begin{abstract}
This study aims to produce modules that are based on the Realistic Matheatics Education (RME) approach to understanding concepts in achieving validity, practicality and effectiveness. This research is a development research in which the research procedure used is the development of a 4-D model namely Define (Design), Design (Development), Development (Development) and Dessiminate (Spread) developed by Thiagarajan in 1974. The results of the first study are validity modules with a percentage of $91.74 \%$ in very valid criteria. The second is freedom value with a percentage of $82.26 \%$ in very practical criteria. The third is the value of effectiveness obtained value of $75.61 \%$ in effective criteria. Thus it can be concluded that the development of modules based on the Realistic Mathematics Education (RME) approach to understanding concepts is classified as valid, practical and effective to use.
\end{abstract}

Keywords: understanding concepts, Realistic Mathematics Education (RME) Approach, Modules.

(C) 2019 LPPM IKIP PGRI Pontianak, Indonesia

\section{PENDAHULUAN}

Pembelajaran adalah proses interaksi peserta didik dengan pendidik dan sumber belajar pada suatu lingkungan belajar. Pembelajaran adalah membelajarkan siswa menggunakan asas pendidikan maupun teori belajar yang merupakan penentu utama keberhasilan pendidikan 
(Sagala, 2009). Pembelajaran merupakan proses komunikasi dua arah. Mengajar dilakukan pihak guru sebagai pendidik, sedangkan belajar oleh peserta didik.

Matematika merupakan salah satu mata pelajaran wajib yang harus dikuasai oleh siswa pada jenjang SD/MI, SMP/Mts, SMA/SMK dan yang lain-lain. Matematika mempunyai sifat yang abstrak yang terdiri dari fakta, operasi atau relasi, konsep dan prinsip. Dalam Permendiknas Nomor 22 Tahun 2006 diuraikan tujuan mata pelajaran matematika diajarkan di sekolah adalah (a) memahami konsep matematika, menjelaskan keterkaitan antar konsep dan mengaplikasikan konsep atau algoritma secara luwes, akurat, efisien dan tepat dalam pemecahan masalah, (b) menggunakan penalaran pada pola dan sifat, melakukan manipulasi matematika dalam membuat generalisasi, menyusun bukti atau menjelaskan gagasan dan pernyataan matematika, (c) memecahkan masalah yang meliputi kemampuan memahami masalah, merancang model matematika, menyelesaikan, model dan menafsirkan solusi yang diperoleh, (d) mengomunikasikan gagasan dengan simbol, tabel, diagram atau media lain untuk memperjelas keadaan atau masalah, dan (e) memiliki sikap menghargai kegunaan matematika dalam kehidupan, yaitu memiliki rasa ingin tahu, perhatian dan minat dalam mempelajari matematika, serta sikap ulet dan percaya diri dalam pemecahan masalah (Depdiknas, 2006).

Salah satu kemampuan yang dikuasai oleh peserta didik sebagai hasil dari proses pembelajaran matematika berdasarkan Permendiknas tersebut adalah memahami konsep matematika. Pemahaman konsep merupakan bagian yang paling penting dalam pembelajaran matematika seperti yang dinyatakan Zulkardi (2003) bahwa: "mata pelajaran matematika menekankan pada konsep". Artinya dalam mempelajari matematika peserta didik harus memahami konsep matematika terlebih dahulu agar dapat menyelesaikan soal-soal dan mampu mengaplikasikan pembelajaran tersebut di dunia nyata. Keberhasilan dalam kegiatan pembelajaran biasanya diukur dengan keberhasilan peserta didik dalam memahami dan menguasai materi yang diberikan.

Kemampuan pemahaman konsep yang rendah terlihat ketika siswa tidak dapat mengaplikasikan konsep dasar pada materi kombinasi dalam penyelesaian soal. Metode mengajar yang sering diterapkan dalam proses pembelajaran adalah metode konvensioanl, pemberian materi hanya dari buku paket dan LKS yang tersedia, dalam proses pembelajaran sering ditemui siswa cenderung malas membaca dan mencatat, karena mencatat materi terlebih dahulu membuat waktu pelajaran berkurang dan membuat pelajaran dikelas menjadi monoton 
dan membosankan, sehingga tujuan dari pembelajaran belum tercapai. Terciptanya pembelajaran yang dapat mengembangkan kemampuan pemahaman konsep pada siswa tidak terlepas dari materi yang akan di pelajari dan bagaimana cara guru menciptakan dan mengelola materi sehingga siswa dapat terlibat aktif untuk memahami konsep suatu materi.

Aktivitas yang sering dilakukan dilakukan guru dalam pembelajaran adalah dengan menerapkan pembelajaran dimana guru memberi materi dan aktivtas siswa mendengarkan. Kemudian guru menjelaskan contoh soal latihan siswa hanya melihat. Hal ini membuat siswa enggan berpikir dan memahami suatu konsep materi, sehingga ketika mengerjakan soal yang berbeda dari contoh soal dan latihan siswa tidak dapat menjawab soal dengan tepat dikarenakan tidak memahami konsep dari materi tersebut (Darma dan Firdaus, 2016).

Upaya yang dapat dilakukan untuk meningkatkan pemahaman siswa adalah dengan mengembangkan bahan ajar yaitu modul menggunakan bahasa sehari-hari yang memudahkan siswa untuk memahami materi. Selain penggunaan bahan ajar dalam pembelajaran, untuk membantu tercapainya tujuan pembelajaran harus menggunakan metode atau pendekatan mengajar yang sesuai dengan permasalahan yang dihadapi. Jadi, untuk menyelesaikan permasalahan kemampuan pemahaman konsep matematika pada siswa dapat menggunakan pendekatan yang berorientasi pada kehidupan sehari-hari, sehingga memudahkan siswa dalam memahami konsep.

Berbagai usaha dikembangkan untuk memperbaiki kualitas pembelajaran. Salah satu cara yang dapat dilakukan adalah mengembangkan media pembelajaran yang berupa bahan ajar. Bahan ajar yang akan dikembangkan adalah bahan ajar modul menggunakan bahasa sehari-hari yang memudahkan siswa untuk memahami materi. Modul sebagai salah satu bahan ajar mempunyai salah satu karakteristik adalah prinsip belajar mandiri. Belajar mandiri menurut Oka (2009) adalah cara belajar aktif dan partisipasi untuk mengembangkan diri masing-masing individu yang tidak terikat dengan kehadiran guru, dosen, pertemuan tatap muka di kelas, kehadiran teman sekolah. Adapun kelebihan pembelajaran dengan modul yaitu (a) modul dapat memberikan umpan balik sehingga pebelajar mengetahui kekurangan mereka dan segera melakukan perbaikan, (b) dalam modul ditetapkan tujuan pembelajaran yang jelas sehingga kinerja siswa belajar terarah dalam mencapai tujuan pembelajaran, (c) modul yang didesain menarik, mudah untuk dipelajari, dan dapat menjawab kebutuhan tentu akan menimbulkan motivasi siswa untuk belajar, (d) modul bersifat fleksibel karena materi 
modul dapat dipelajari oleh siswa dengan cara dan kecepatan yang berbeda, (e) kerjasama dapat terjalin karena dengan modul persaingan dapat diminimalisir dan antara pebelajar dan pembelajar, dan (f) remidi dapat dilakukan karena modul memberikan kesempatan yang cukup bagi siswa untuk dapat menemukan sendiri kelemahannya berdasarkan evaluasi yang diberikan.

Selain penggunaan bahan ajar dalam pembelajaran, untuk membantu tercapainya tujuan pembelajaran harus menggunakan metode atau pendekatan mengajar yang sesuai dengan permasalahan yang dihadapi. Jadi, untuk menyelesaikan permasalahan kemampuan pemahaman konsep matematika pada siswa dapat menggunakan pendekatan yang berorientasi pada kehidupan sehari-hari, sehingga memudahkan siswa dalam memahami konsep. Berdasarkan hal tersebut, pendekatan Realistic Mathematics Education (RME) dianggap mampu menyelesaikan masalah kemampuan pemahaman konsep. Realistic Mathematics Education (RME) adalah pendekatan pembelajaran matematika dari hal yang nyata bagi siswa. Realistic Mathematics Education (RME) diterjemahkan sebagai pendidikan matematika realistik (PMRI), adalah suatu pendekatan belajar matematika yang dikembangkan sejak tahun 1971 oleh sekelompok ahli matematika dari Freudenthal Institute, Utrecht Universitty di Belanda. Pendekatan ini didasarkan pada anggapan Hans Freudenthal (1905-1990) bahwa matematika adalah kegiatan manusia (Marja \& Panhuzen, 2003). Dari beberapa uraian tersebut, tujuan dari penelitian ini adalah mengembangkan modul berbasis pendekatan Realistic Mathematics Education (RME) terhadap pemahaman konsep dalam materi peluang pada siswa kelas XII SMK Koperasi Pontianak.

\section{METODE}

Metode yang digunakan dalam penelitian ini adalah metode penelitian dan pengembangan atau penelitian Research and Development (R\&D). Dalam pelakasanaan penelitian Research and Development $(R \& D)$ ini yang digunakan adalah pendekatan atau pengembangan model 4-D. Model 4-D dikembang oleh Thiagarajan (1974) yang merupakan singkatan dari define (pendefinisian), design (perancangan), development (pengembangan) and dissemination (penyebaran. Subjek ujicoba produk pada penelitian ini adalah siswa kelas XII SMK Koperasi Pontianak yang berjumlah 41 siswa. 


\section{HASIL DAN PEMBAHASAN}

\section{Tahap Pendefinisian (Define)}

Tahap pendefinisian ini dilakukan untuk mengidentifikasi kebutuhan berdasarkan analisis dari permasalahan yang ditemukan. Pada tahap analisis awal yang dilakukan peneliti adalah menentukan masalah. Setelah mengidentifikasi masalah yang dialami siswa, maka peneliti pun menentukan solusi yang akan ditawarkan. Pada tahap analisis siswa, peneliti melakukan wawancara terhadap guru. Wawancara ini bertujuan untuk menganalisis masalah yang dialami siswa. Hal-hal ynag ditanyakan antara lain terkait siswa, biodata guru mata pelajaran matematika, materi pembelajaran, strategi pembelajaran, dan media pembelajaran. Anaslisis tugas diperoleh berdasarkan hasil wawancara dan langkah pengerjaan siswa dalam materi peluang khususnya sub bab kombinasi, guru menyimpulkan bahwa siswa tidak memahami konsep pada materi kombinasi. Oleh karena itu, peneliti memilih materi kombinasi untuk dijadikan materi penelitian. Berdasarkan hasil analisis di atas, diperoleh analisis konsep sehingga model pembelajaran yang digunakan sekolah tersebut adalah model pembelajaran tipe jigsaw. Selain itu, media pembelajaran yang pernah digunakan disekolah tersebut adalah infocus dan LKS. Untuk itu, peneliti menawarkan untuk mengembangkan modul berbasis pendekatan Realistic Mathematics Education (RME) yang diharapkan dapat memudahkan siswa untuk memahami konsep. Berdasarkan hasil pra observasi didapati siswa masih kesulitan menyelesaikan soal kerena tidak memahami konsep materi peluang yaitu pada sub materi kombinasi. Adapun materi, standar kompetensi, kompetensi dasar, indikator pembelajaran, dan tujuan pembelajaran yang dimaksud dalam materi tersebut disajikan pada Tabel 1.

Tabel 1. Identifikasi Tujuan Pembelajaran

\begin{tabular}{|c|c|c|}
\hline No & Identifikasi & Hasil Identifikasi \\
\hline 1. & Materi & Peluang yaitu pada subbab kombinasi \\
\hline 2. & Standar Kompetensi & $\begin{array}{l}\text { Menggunkan aturan perkalian, permutasi, dan kombinasi } \\
\text { dalam pemecahan masalah }\end{array}$ \\
\hline 3. & Kompetensi Dasar & $\begin{array}{l}\text { Menyajikan penyelesaian masalah kontekstual yang } \\
\text { berkaitan dengan kombinasi } \\
\text { 1. Menyatakan kombinasi }\end{array}$ \\
\hline 4. & Indikator Pembelajaran & $\begin{array}{l}\text { 2. Menerangka kombinasi } \\
\text { 3. Menggunakan kombinasi }\end{array}$ \\
\hline 5 . & Tujuan Pembelajaran & $\begin{array}{l}\text { 1. Dapat menjelaskan konsep kombinasi } \\
\text { 2. Dapat menerapkan konsep kombinasi } \\
\text { 3. Dapat menyelesaikan masalah tentang kombinasi }\end{array}$ \\
\hline
\end{tabular}




\section{Tahap perancangan (Design)}

Tahap perancangan terdiri dari 4 tahap, yaitu sebagai berikut.

\section{a. Penyusunan Tes}

Pada tahap ini, peneliti menyusun instrumen untuk menilai kevalidan, kepraktisan, dan keefektifan modul. Penyusunan instrumen tesdibagi menjadi 2 langkah, yaitu :

\section{1) Langkah Pertama}

Pada langkah pertama, peneliti menyusun kisi-kisi lembar validasi, kisi-kisi angket, dan kisi-kisi soal uji coba. Kisi-kisi angket dalam aspek materi yang disusun sebanyak 4 aspek yaitu, kelayakan isi (12 butir pertanyaan), kelayakan penyajian (9 butir pertanyaan), penilaian bahasa (9 butir pertanyaan), penilaian Realistic Mathematics Education (RME) (1 butir pertanyaan). Sedangkan aspek media disusun sebanyak 1 aspek yaitu, aspek kelayakan kegrafikan dengan 3 indikator antara lain ukuran modul (2 butir pertanyaan), desain sampul ( 5 butir pertanyaan) dan desain isi (7 butir pertanyaan).

2) Langkah kedua

Pada langkah kedua, peneliti menyusun lembar validasi, angket dan soal uji coba sesuai dengan kisi-kisi yang telah dibuat pada langkah pertama. Butir pertanyaan yang diperoleh dari ahli materi 35 butir pertanyaan dan ahli media 24 butir pertanyaan sehingga total pertanyaan sebanyak 59 butir pertanyaan.

\section{b. Pemilihan Media}

Pada tahap ini, peneliti memutuskan untuk memilih modul sebagai media dalam penelitian.

\section{c. Pemilihan Format}

Secara garis besar modul ini terdiri dari halaman sampul berwarna dan bergambar, kata pengantar, pendahuluan, daftar isi, tujuan pembelajaran, petunjuk guru, isi, lembar evaluasi, kunci lembar evaluasi dan daftar pustaka. Isi yang tertera pada modul memenuhi hal-hal berikut:

1) Sesuai dengan kurikulum KTSP

2) Penyajian materi diberi warna untuk menarik perhatian dan minat baca siswa.

3) Materi yang disajikan sesuai dengan standar kompetensi, kompetensi dasar dalam silabus

4) Ringkasan materi

5) Contoh soal yang penyelesaian soal berbasis Realistic Mathematics Education (RME). 
6) Latihan soal berbentuk lembar kegiatan siswa yang disediakan langkah-langkah penyelesaiannya berbasis Realistic Mathematics Education (RME).

7) Soal tes berbentuk lembar kerja siswa

8) Kunci lembar kerja siswa

d. Desain Awal

Pada tahap ini, kegiatan yang dilakukan adalah mendesain modul. Berikut adalah desain awal modul berbasis pendekatan Realistic Mathematics Education (RME).

1) Halaman Sampul (Cover)

Halaman sampul adalah bagian awal dari modul. Pada halaman sampul ini terdapat nama penulis, judul modul beserta gambar, serta kolom untuk menulis nama dan kelas siswa yang menggunakan modul.

2) Halaman Kata Pengantar

Kata pengantar menjadi halaman pembukaan dari modul ini.

3) Halaman Daftar Isi

Daftar isi digunakan untuk memudahkan menemukan halaman dari isi modul.

4) Halaman Pendahuluan

Halaman pedahuluan berisi tentang deskripsi, kompetensi dasar dan standar kompetensi, petunjuk penggunaan modul, tujuan akhir dan soal tes kemampuan.

5) Halaman Isi (Materi Pembelajaran, Contoh Soal, Latihan Soal, dan Soal Evaluasi)

Halaman isi berisi materi pembelajaran yang disajikan sesuai dengan langkah-langkah pendekatan Realistic Mathematics Education (RME).

6) Halaman Daftar Pustaka

Halaman daftar pustaka berisi tentang sumber atau referensi yang digunakan untuk membuat modul.

7) Halaman Profil Penulis

Halaman profil penulis memuat biodata tentang penulis serta memuat nama para validator.

\section{Tahap Pengembangan}

Tahap pengembangan ini bertujuan untuk memperbaiki modul yang akan dikembangkan dengan melakukan evaluasi dan revisi sebelum menjadi produk yang valid, praktis dan efektif. Validasi digunakan untuk mengetahui kevalidan modul. Hasil validasi modul disajikan pada Tabel 2. 
Tabel 2. Hasil Validasi

\begin{tabular}{ccccc}
\hline Ahli & Bidang Ahli & Skor Total & Rata-rata & Kriteria \\
\hline 1. & Materi dan Media & 273 & $92,4 \%$ & Sangat Valid \\
2. & Materi dan Media & 277 & $94,2 \%$ & Sangat Valid \\
3. & Materi dan Media & 263 & $88,6 \%$ & Sangat Valid \\
\hline
\end{tabular}

Dengan demikian, diperoleh hasil kevalidan dalam kriteria sangat valid. Soal uji coba yang divalidasi oleh semua ahli juga tergolong valid semua dan dapat diujicobakan. Uji coba lapangan dilakukan di SMK Koperasi Pontianak khusus pada siswa kelas XII RPL (Rekayasa Perangkat Lunak).

Pertama, guru matematika memberikan pengajaran kepada siswa kelas XII RPL dengan menerapkan modul berbasis pendekatan Realistic Mathematics Education (RME). Kedua, Ibu guru meminta siswa untuk mengerjakan soal posstest dengan menggunakan soal uji coba. Pengerjaan posstest ini digunakan untuk melihat keefektifan dari modul tersebut. Soal diberikan kepada siswa dengan waktu pengerjaan selama $2 \times 45$ menit. Ketiga, Ibu guru dan saya memberikan angket respon kepada seluruh siswa untuk menilai modul yang telah digunakan.

Setelah diuji coba dilapangan, modul ini siap dikemas menjadi produk akhir. Guru matematika di tempat uji coba tidak memberikan saran apa pun. Beliau hanya berpendapat bahwa modul ini memudahkan Ia dalam menyampaikan materi dan dapat membantu siswa untuk lebih mudah memahami konsep materi yang terdapat dalam modul berbasis pendekatan Realistic Mathematics Education (RME). Dengan demikian, modul ini sudah bisa dicetak kembali dan digunakan sebagai produk akhir.

Modul pembelajaran yang berkualitas memperhatikan komponen-komponen yang ditetapkan oleh Badan Standar Nasional Pendidikan (BSNP) yaitu komponen aspek kelayakan isi, aspek bahasa dan gambar, aspek penyajian dan kegrafisan. Adapun hasil dari penilaian terhadap modul untuk beberapa aspek yang telah disebutkan, berdasarkan hasil data, diperoleh bahwa modul pembelajaran pada setiap komponen aspek kelayakan isi, aspek bahasa dan gambar, penyajian dan kegrafisan untuk siswa SMK layak digunakan dengan kriteria sangat valid.

Berdasarkan hasil penelitian dan hasil analisis terhadap data setelah perlakuan, diperoleh kesimpulan bahwa modul pembelajaran matematika efektif ditinjau dari pemahaman konsep. Hal ini disebabkan karena modul yang dikembangkan berbasis pendekatan 
Realistic Mathematics Education (RME). Dimana pendekatan ini sesuai dengan masalah yang dialami siswa yaitu kesulitan dalam memahami konsep.

Dari hasil penelitian, terlihat bahwa lebih dari setengah jumlah siswa yang mendapatkan nilai tuntas sesuai dengan KKM yaitu 75 pada pengerjaan soal posttest. Dalam proses pembelajaran siswa dapat mengikuti pembelajaran dengan baik dan guru lebih mudah menyampaikan materi kepada siswa, sehingga proses pembelajaran berjalan dengan lancar dan siswa dapat memahami materi yang tersedia didalam modul dengan mandiri tanpa bantuan dari guru seperti pada saat belajar di rumah.

Dari hasil nilai siswa tersebut terlihat bahwa siswa dapat memahami materi yang disampaikan dengan menggunakan pendekatan Realistic Mathematics Education (RME). Maka dari hal tersebut dapat disimpulkan bahwa modul berbasis pendekatan Realistic Mathematics Education $(R M E)$ dapat meningkatkan pemahaman siswa pada materi kombinasi.

\section{SIMPULAN}

Berdasarkan hasil penelitian dan pembahasan, maka diperoleh simpulan bahwa, terdapat peningkatan pemahaman konsep siswa yang menggunakan modul. Untuk kevalidan modul pembelajaran berkriteria sangat valid dan layak digunakan ditinjau dari aspek kelayakan isi, aspek bahasa dan gambar, aspek penyajian dan aspek kegrafisan yang diperoleh dari penilaian para validator. Untuk kepraktisan berkriteria sangat praktis ditinjau dari hasil pengisian angket respon siswa setelah penggunaan modul dalam proses pembelajaran. Dan untuk keefektifan berkriteria efektif ditinjau dari hasil postest siswa. Produk pengembangan berupa modul berbasis pendekatan Realistic Mathematics Education (RME) terhadap pemahaman konsep dalam materi peluang pada siswa kelas XII SMK Koperasi Pontianak dapat digunakan pada tingkat atau jenjang yang lebih tinggi, selain untuk pembelajaran individu dan mandiri dapat digunakan secara klaksikal tergantung pada metode pembelajaran yang digunakan. Pengembangan seperti ini dapat dilakukan pada konsep lain yang lebih luas mencakup materi yang lebih lengkap sehingga diharapkan dapat meningkatkan aspek afektif maupun kognitif. 


\section{DAFTAR PUSTAKA}

BSNP. (2007). Pedoman memilih menyusun bahan ajar dan teks mata pelajaran panduan tingkat satuan pendidikan menengah SMA/MA. Jakarta: Badan Standar Nasional Pendidikan.

Darma, Yudi \& Firdaus, Muhamad. (2016). Mengembangkan Kemampuan Pemecahan Masalah Melalui Pembelajaran Strategi Heuristik dengan Pendekatan Metakognitif Ditinjau dari Kemandirian Belajar Mahasiswa Calon Guru Matematika. Jurnal Ilmiah Pendidikan Matematika. 5(1), 1-10.

Depdiknas. (2006). Peraturan menteri pendidikan nasional nomor 22 tahun 2006 tentang standar isi untuk satuan pendidikan dasar dan menengah. Jakarta: Depdiknas.

Marja dan Panzhuen. (2003). The Didactical Use of Models In Realistic athematics Education: an Example From a Longitudinal Trajectory on Persentage. Journal Educational Studies in Mathematics, 5, 9-35.

Oka, A.A. (2009). Pengaruh penerapan belajar mandiri pada materi ekosistem terhadap keterampilan berpikir kritis dan kemampuan memecahkan masalah siswa SMA di kota Metro. Diakses pada tanggal 1 Oktober 2012 dari http://www.ummetro.ac.id/file_jurnal/5.\%20Anak\%20Agung\%20Oka\%20UM\%20Metro. $p d f$.

Sagala, S. (2009). Konsep dan makna pembelajaran. Bandung: Alfabeta.

Soedjadi. (2003). Pembelajaran Matematika Berjiwa RME. Makalah disampaikan pada seminar nasional PMRI di Universitas Sanata Darma. Yogyakarta.

Thiagarajan, S dkk. (1974). Instruction Develpment for Training Teachers of Exceptional Children. Washinton DC: National Center for Improvement Education System.

Zulkardi. (2003). Pendidikan matematika di Indonesia: beberapa permasalahan dan upaya penyelesaiannya. Palembang: Unsri 